\title{
Microbiological Diversity and Biotechnological Potential of the Soil Ecosystem of a High-Mountainous Landfill
}

\author{
Nurzat Totubaeva*, Zhiide Tokpaeva, Akjol Akjigit Uulu, \\ Kanatbek Kojobaev \\ Department of Environmental Engineering, Kyrgyz-Turkish Manas University, \\ Bishkek, Kyrgyz Republic
}

Received: 17 July 2018

Accepted: 21 November 2018

\begin{abstract}
Strains isolated from high mountain industrial landfills have high biotechnological potential and studying their diversity is relevant. The objective of this study was to investigate the microbial diversity of oil-contaminated soils at a high mountain mine located 4000 meters above sea level, isolated and characterized by hydrocarbon-resistant bacteria and compare the degradation efficiency of two bacterial consortia. The surface layer $(0-30 \mathrm{~cm})$ that consists of $10440 \mathrm{mg} / \mathrm{kg}$ hydrocarbons were used for the experiment. A bacteria group of the three genera Pseudomonas, Flavobacterium, and Rhodococcus dominated. Fungi Aspergillus, Penicillium, and Trichoderma were present in relatively high abundances in the samples. The study shows that the actinomycetes of the Streptomyces group of the Cinereus section are most sensitive to hydrocarbon contamination. Three superior indigenous bacteria Rhodococcus rhodococcus N1, Pseudomonas fluorescens W3, and Flavobacterium NE2 has been isolated from oilpolluted soil. The consortium composed of bacteria strains Rhodococcus rhodococcus N1, Pseudomonas fluorescens W3, and Flavobacterium NE2 is more effective than a consortium composed of bacteria strains Rhodococcus rhodococcus N1, Pseudomonas fluorescens W3 hydrocarbon removal efficiency $70 \%$ and $22.9 \%$, respectively. These findings provide highly valuable information on the production of bacterial consortium for the remediation of oil-contaminated soil.
\end{abstract}

Keywords: high-mountainous landfill; oil-contaminated soil; biodiversity; consortium

\section{Introduction}

Kumtor, the largest gold mine in Central Asia, is located southeast of the Kyrgyz Republic at an altitude of $4000 \mathrm{~m}$ a.s.1. in a partially glaciated permafrost zone

*e-mail:totubaevanurzat@gmail.com at $41^{\circ} 52^{\prime} \mathrm{N}$ and $78^{\circ} 11^{\prime} \mathrm{E}$. Its climate is continental, with an average annual temperature of $-8^{\circ} \mathrm{C}$ [1]. The Kumtor complex is in close proximity to the active glaciers [2] belonging to the Naryn River basin, which has international importance [3]. As a result of the largescale activity of the Kumtor gold mine, only 162.9 tons of oiled rags were formed at the landfill site between 2014 and 2016, which relate to dangerous waste of 
classes 3 and 4 [1]. In turn, we are facing the task of remediation and biodiversity conservation of microbial communities of the mining complex's landfill with the aim of their sustainable functioning.

It is common knowledge that among the various technogenic disturbances in nature, oil pollution is one of the most serious and hard to eliminate [4]. Oil and its components (aromatic, naphthenic and paraffinic hydrocarbons) [5] are among the most dangerous pollutants that enter soil and water ecosystems in the processes of extraction, transportation, processing, and storage [6-11]. To accelerate the process of self-cleaning of soils from oil, all natural reserves of the ecosystem are used, including biological ones. Microbiological methods of soil purification are able to supplement various technologies [12, 13] and in certain situations have no analogs [1417]. Biodiversity, especially the microbiodiversity of both indigenous ecosystems and those prone to anthropogenic pressure, is the key to finding ecological methods for maintaining and restoring disturbed ecosystems [18-20].

The study of the biodiversity of microorganisms and the responses of biota give an idea not only of the state of the biota but also allow us in many cases to predict its development as a whole ecosystem [17, 21]. A soil is the most diverse environment on Earth [22], and many of the local microorganisms have the ability to resist and degrade hydrocarbons of crude oil [23-26]. A number of scientists have established the important role of hydrocarbon oxidizing microorganisms in the processes of biodegradation of various classes of hydrocarbons in oil and oil products [27-31]. Some microorganisms are able to degrade hydrocarbons of crude oil, which is the goal for research aimed at mitigating any possible consequences of soil contamination [32-35]. Oil degenerative strains are usually isolated from polycyclic aromatic hydrocarbon of polluted soils. However, little is known about the ecology and diversity of indigenous populations of these microorganisms in contaminated environments [36].

The aim of our work was to investigate the biodiversity of indigenous microorganisms of soil from hazardous waste landfill of Kumtor mine and to search for a potentially active strain-destructor of oil products.

\section{Material and Methods}

\section{Sample Collection}

Soil samples were gathered from the hazardous waste landfill of Kumtor mine in September at an air temperature of $5^{\circ} \mathrm{C}$, humidity of $45 \%$ and pressure of $658.5 \mathrm{~mm} \mathrm{Hg}$. Background soil sample was gathered $200 \mathrm{~m}$ from the landfill. Soil samples were collected from five random points in each site to a depth of 0-30 cm. The samples were combined, dried, sieved
( $2 \mathrm{~mm}$ mesh), placed in a plastic bag and stored at $4^{\circ} \mathrm{C}$ until used.

\section{Chemical Analyses}

The $\mathrm{pH}$ was measured in triplicate using a Horiba B-213 twin $\mathrm{pH}$ meter after extraction of soil using onepart solid to 2.5 parts of distilled water.

Estimation of total concentrations of hydrocarbons in soil samples was determined at the accredited laboratory of the State Agency for Environmental Protection and Forestry under the government of the Kyrgyz Republic.

$5 \mathrm{~g}$ soil samples were mixed with $40 \mathrm{~mL}$ of dichloromethane as the extraction solvent. Then hydrocarbon extraction was performed using a Soxhlet extractor. Solvent extract after cleanup and concentration was analyzed using a Shimadzu gas chromatograph (Japan) equipped with a flame ionization detector and a 30 -m-long $0.25 \mathrm{~mm}$ i.d. (0.25 $\mu \mathrm{m}$ film thickness). Oven temperature was kept at $100^{\circ} \mathrm{C}$ for $1 \mathrm{~min}$, then ramped up at $10^{\circ} \mathrm{C} / \mathrm{min}$ to $250^{\circ} \mathrm{C}$ and kept at this temperature for $5 \mathrm{~min}$. The injector temperature was $280^{\circ} \mathrm{C}$. Carrier gas flow was $31 \mathrm{~cm} / \mathrm{s}$.

Hydrocarbons removal efficiency (E\%) was measured as the percentage of removal in accordance with the following equation: $\mathrm{E} \%=\frac{C i-C f}{C i} 100 \%$, where $\mathrm{C}_{\mathrm{i}}$ and $\mathrm{C}_{\mathrm{f}}$ are the initial and final hydrocarbon concentrations.

\section{Microbial Analyses}

The number of microorganisms was determined by the plate method. Ten grams of each soil sample was added to $90 \mathrm{~mL}$ of distilled water. The solution was diluted $\left(10^{-1}\right.$ to $\left.10^{-6}\right)$ and aliquots of the resulting solutions plated on appropriate culture media. Czapek media was used for fungal growth, meat-peptone agar (MPA) for bacteria growth and starch-ammonia agar (SAA) for actinomycetes growth. All experiments were performed in triplicate. After incubation at 25 or $30^{\circ} \mathrm{C}$ for up to 10 days, the colony forming units (CFU) were counted [37]. In addition, the cultures were determined according to macromorphological types.

\section{Isolation and Detection of Bacteria from Samples}

To isolate hydrocarbon-degrading bacteria from hazardous landfill, soil samples were taken on the Voroshilova-Dianova (VD) medium, contained, per liter: $\mathrm{NH}_{4} \mathrm{NO}_{3} 1.0 \mathrm{~g}, \mathrm{~K}_{3} \mathrm{HPO}_{4} 1.0 \mathrm{~g}, \mathrm{~K}_{2} \mathrm{HPO}_{4} 1.0 \mathrm{~g}, \mathrm{MgSO}_{4}$ $0.2 \mathrm{~g}, \mathrm{CaCl}_{2} 0.02 \mathrm{~g}, \mathrm{FeCl}_{2}-2$ drops of concentrated solution, with sterile $1 \%$ crude oil as the sole carbon source. $5 \mathrm{ml}$ of crude oil and oil-contaminated soil sample was added in a $250 \mathrm{ml}$ Erlenmeyer flask with a liquid medium. The suspension was shaken in an orbital shaker at $200 \mathrm{rpm}$ and incubated at $30^{\circ} \mathrm{C}$ for 15 days. Pure bacteria strains were isolated by traditional spread technique on meat-and-peptone agar (MPA). 
For selection of oil-degrading microorganisms, each isolate suspended in $100 \mathrm{ml}$ of VD medium with $1 \%$ oil. Bacteria were grown for 7 days on the shaker at $200 \mathrm{rpm}$. The bacteria able to grow on oil contained medium were monitored spectrophotometrically at $590 \mathrm{~nm}$.

The key features in determining the bacterial generic membership were: mobility, bacterial colony characteristics, Gram staining, availability of oxidase and catalase. The shape and mobility of the cells were determined by microscopy of living bacterial preparations. Morphological features were detected on fixed preparations stained with fuchsin or methylene blue according to microbiological standard methods [38].

- Catalase test: One drop of hydrogen peroxide $\left(3 \% \mathrm{H}_{2} \mathrm{O}_{2}\right.$ ) solution was placed on the glass slide. A single colony of overnight grown culture was mixed with the $\mathrm{H}_{2} \mathrm{O}_{2}$ drop. The formation of bubbles after 5 minutes indicated the presence of catalase.

- Oxidase test: Oxidase reagent ( $1 \%$ tetramethyl-pphenylenediamine dihydrochloride) was prepared, and filter paper was moistened with this reagent. Overnight grown organisms were smeared over the paper with the help of a glass rod or plastic loop or platinum wire. Change in color was observed within 10-20 s. The formation of purple color shows the presence of oxidase.

\section{Biodegradation Experiments}

The ability of isolated microorganisms to decompose petroleum products was carried out under laboratory conditions. Approximately 500g of contaminated soil sample $(10440 \mathrm{mg} / \mathrm{kg})$ were placed into each container. The following experiments were carried out: Consortium 1 in soil sample inoculating the monoculture of two strains of Rhodococcus N1 + Pseudomonas W3; Consortium 2 in soil sample inoculated the monoculture of three strains of Rhodococcus N1 + Pseudomonas W3 + Flavobacterium NE2; and Control in soil sample wasn't inoculated strains. Each experiment was tested in triplicate. Cultivation was carried out for 30 days at room temperature $+24-28^{\circ} \mathrm{C}$; soil aeration and moisture $(60 \%)$ were controlled daily.

\section{Results and Discussion}

The content of oil products in the contaminated soil sample was $10440 \mathrm{mg} / \mathrm{kg}$, while the background sample contained $320 \mathrm{mg} / \mathrm{kg}$. The reaction of the soil solution affecting the characteristics of the functioning of microorganisms in accordance with the analytical data was neutral $\mathrm{pH}$ value $=6.9$.

The study of the bacteria microflora showed that the species diversity of bacteria was insignificant. Five species of bacteria of the genera Pseudomonas, Rhodococcus, Flavobacterium, Bacillus, and Nocardia

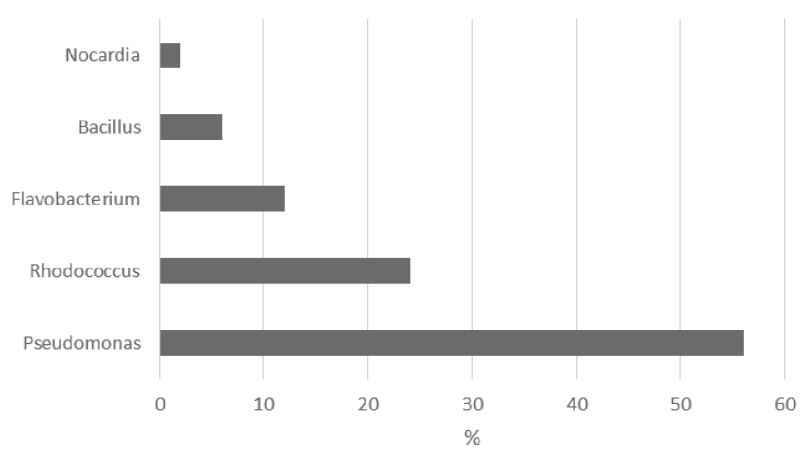

Fig. 1. Percentage expression of bacterial species in test samples.

were identified and among them the percentage of three species of bacteria Pseudomonas, Rhodococcus, and Flavobacterium dominated (Fig. 1), which confirmed their activity in the destruction of petroleum products and bacterial capability for resistance and adaptability to high contamination levels [39-44]. Similar results were obtained by other researchers of Antarctic soils, where in oil-contaminated soil dominated Proteobacteria, mainly by the genera Pseudomonas, Rhodococcus, Sphingomonas, and Variovorax $[45,46]$.

Representatives of dark-colored fungi predominated over light-colored fungi in contaminated soil, while in the sample of the background soil light-colored forms of fungi predominated (Fig. 2). The greatest count of CFUs of fungi also was contained in the contaminated sample $\left(6 * 10^{5} \mathrm{CFU}\right)$ and the background sample B $\left(2.1 * 10^{5} \mathrm{CFU}\right)$. It should be noted that the biodiversity of micromycetes was minimal, limited only by 5 genera: Aspergillus, Penicillium, Acremonium, Fusarium, and Trichoderma. Our studies have revealed that oil products have a toxic effect on the soil microbiota, inhibiting its biological diversity and in the dominance of the most resistant species of fungi. The same results were obtained by other researchers [47-52]. Many researchers confirmed that the diversity of the fungal community is dominant among other inhabitants in the oil contamination of soils. Apparently, Aspergillus and Penicillium are the most common species in high oil-contaminated soils [53-56].

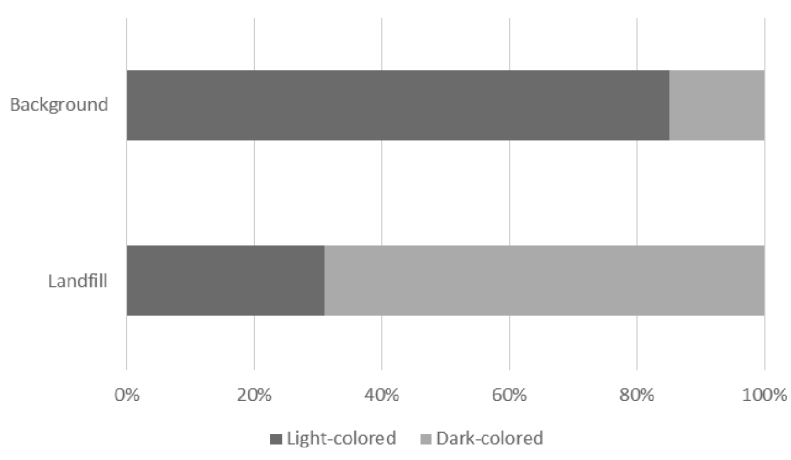

Fig. 2. Abundance of dominant groups of fungi (\%). 
Table 1. Characteristics of superior strains isolated form contaminated soil.

\begin{tabular}{|c|c|c|c|c|c|c|}
\hline Strain & $\begin{array}{c}\text { Macroscopic } \\
\text { characteristics }\end{array}$ & $\begin{array}{c}\text { Microscopic } \\
\text { characteristics }\end{array}$ & $\begin{array}{c}\text { Mobility } \\
\text { test }\end{array}$ & $\begin{array}{c}\text { Grams staining } \\
\text { test }\end{array}$ & $\begin{array}{c}\text { Catalase } \\
\text { test }\end{array}$ & $\begin{array}{c}\text { Oxidase } \\
\text { test }\end{array}$ \\
\hline W3 & $\begin{array}{c}\text { Smooth edge, mucoid, } \\
\text { and milky color }\end{array}$ & Small bacil & Positive & Negative & Positive & Negative \\
\hline N1 & $\begin{array}{c}\text { Smooth edge, mucoid, } \\
\text { and milky color }\end{array}$ & Small cocci & Negative & Positive & Negative & Negative \\
\hline NE2 & $\begin{array}{c}\text { Smooth edge, mucoid, } \\
\text { and milky color }\end{array}$ & Small bacil & Negative & Negative & Positive & Positive \\
\hline
\end{tabular}

Table 2. Content of oil in soils according to the variants of the experiment.

\begin{tabular}{|c|c|c|c|}
\hline & $\begin{array}{c}\text { Initial content of total hydrocarbon, } \\
\mathrm{mg} / \mathrm{kg}\end{array}$ & $\begin{array}{c}\text { Content of total hydrocarbon after 1 month, } \\
\mathrm{mg} / \mathrm{kg} \pm \mathrm{SD}\end{array}$ & $\begin{array}{c}\text { Total hydrocarbon } \\
\text { removal efficiency E\% }\end{array}$ \\
\hline Control & 10440 & $8080 \pm 58,6$ & 23 \\
\hline Consortium 1 & 10440 & $7343 \pm 61,5$ & 30 \\
\hline Consortium 2 & 10440 & $3097 \pm 36,5$ & 70 \\
\hline
\end{tabular}

SD - standard deviation

The study of actinomycetes showed that this group did not contain a large species diversity, and the group was mainly represented by the Cinereus section of the genus Streptomyces, in a minor amount. Representatives of other sections could not be singled out for us. Perhaps this group has minimal properties to absorb hard-toreach hydrocarbons.

In a model laboratory experiment, as a result of screening, more than 70 strains were isolated and three indigenous bacterial strains which showed the greatest oil-consuming activity were identified. Table 1 presents the characteristics of these three isolates. The use of bacterial consortia consisting of isolated natural sources is considered to be more appropriate than using monocultures, as noted by many authors [39, 57-59], which was also confirmed by our studies. So the introduction of consortia based on two strains of microorganisms Pseudomonas W3 and Rhodococcus N1 contributed to a 1.3-fold decrease in oil content and the introduction of a consortium

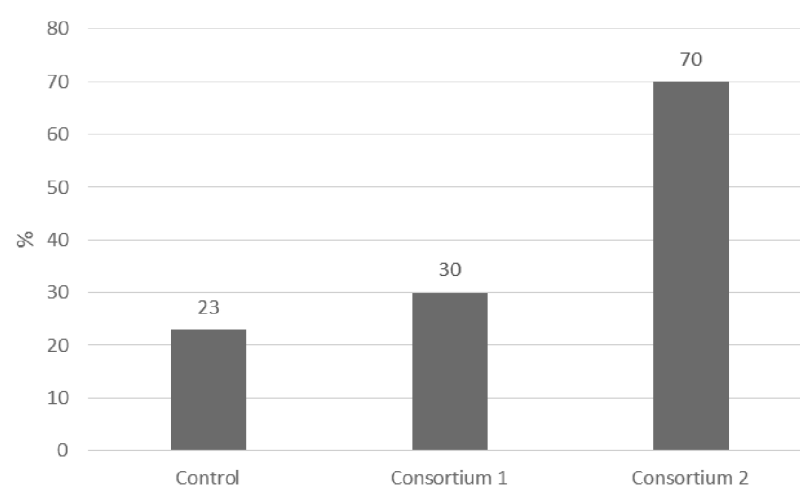

Fig. 3. Hydrocarbon removal efficiency within 30 days. of 3 strains of microorganisms Pseudomonas W3, Rhodococcus N1, and Flavobacterium NE2 contributed to a 3.11-fold decrease in oil content compared to control. From the data of Table 2, it follows that the natural process of self-cleaning of soils from oil in the creation of favorable conditions led to the destruction of oil by $23 \%$. In soils with the introduction of consortia 1 and consortia 2, the purification process increased to $30 \%$ and $70 \%$ (Fig. 3). The most effective was consortium 2. Identified strains of bacteria have the most active properties for the destruction of oil products. The introduction of indigenous strains for further remediation of soil from the landfill is a good prospect, as strains of microorganisms are adapted to the extreme climatic conditions of the Kumtor region.

\section{Conclusions}

Our research has shown that despite the climatic conditions of Kumtor, regional microorganisms quite successfully coped with the role of decomposers - oil products in particular. However, the microbiological diversity of the landfill soil is sparse and mainly represented by resistant microorganisms: bacteria of the genera Pseudomonas, Flavobacterium and Rhodococcus; fungi Aspergillus, Penicillium, Trichoderma, which indicates the weak stability of the soil ecosystem in relation to anthropogenic pressure. Highly sensitive to the contamination of petroleum products were actinomycetes of the genus Streptomyces of the Cinereus section. Three indigenous bacterial isolates Pseudomonas W3, Rhodococcus N1 and Flavobacterium NE2 showed how they work as a consortium. Best hydrocarbon removals were observed 
in soils inoculated with three strains of bacteria (consortium 2) $70 \%$, while in the binary consortium (consortium 1) hydrocarbon removals were $30 \%$. We established that, despite the active action of the enterprise, soil microorganisms quite successfully fulfill their ecological functions and carry out the degradation of hydrocarbon products. The study of microorganisms communities of soil hazardous waste landfill of Kumtor mine is a priority in the environmental management of waste. Therefore, obtained results of this work can form the basis for further work on bioremediation.

\section{Conflict of Interest}

The authors declare no conflict of interest.

\section{References}

1. Kumtor annual report on the protection of the environment and sustainable development for the 2016, 1, 2016.

2. PETRAKOV D.A., LAVRIENTIEV I.I., KOVALENKO N.V., USUBALIEV R.A. Ice thickness, volume and modern change of the Sary-Tor glacier area (Ak-shyirak massif, inner Tian Shan). Cryosphere of the Earth. 18, 91, 2014.

3. ATLAS OF THE KIRGIZ SSR. Moscow: MDGC USSR, 1, 157, 1987.

4. SHENG Y., WANG G., HAO C., XIE Q., ZHANG Q. Microbial community structures in petroleum contaminated soils at an oil field, Hebei, China. CleanSoil, Air, Water 44 (7), 1, 2016.

5. FALKOVA M., VAKH C., SHISHOV A., ZUBAKINA E., MOSKVIN A., MOSKVIN L., BULATOV A. Automated IR determination of petroleum products in water based on sequential injection analysis. Talanta 148, 661, 2016.

6. BROSZEIT S., HATTAM C., BEAUMONT N. Bioremediation of waste under ocean acidification: reviewing the role of Mytilus edulis. Marine Poll. Bull. 103, 5, 2016.

7. LI X., WANG X., REN Z.J., ZHANG Y., LI N., ZHOU Q. Sand amendment enhances bioelectrochemical remediation of petroleum hydrocarbon contaminated soil. Chemosphere 141, 62, 2015.

8. RIVEROLL-LARIOS J., ESCALANTE-ESPINOSA E., FÓCIL-MONTERRUBIO R.L., DÍAZ-RAMÍREZ I.J. Biological activity assessment in Mexican tropical soils with different hydrocarbon contamination histories. Water Air Soil Pollut. 226 (10), 353, 2015.

9. VARJANI S.J. Remediation processes for petroleum oil polluted soil. Indian J. Biotechnol. 16 (2), 157, 2017.

10. WANG W., ZHONG R., SHAN D., SHAO Z. Indigenous oil-degrading bacteria in crude oil contaminated seawater of the Yellow sea, China. Appl. Microbiol. Biotechnol. 98 (16), 7253, 2014.

11. KUMAR S., BHARTI D., SHAZIB S.U. A., SHIN M.K. Discovery of a new hypotrich ciliate from petroleum contaminated soil. Plos One 12 (6), e0178657, 2017.

12. CSUTAK O., STOICA I., GHINDEA R., TANASE A.M., VASSU T. Insights on yeast bioremediation processes. Roman. Biotechnol. Lett. 15, 5066, 2010.
13. IHEANACHO C.C., OKERENTUGBA P.O., ORJI F.A., ATAIKIRU T.L. Hydrocarbon degradation potentials of indigenous fungal isolates from a petroleum hydrocarbon contaminated soil in Sakpenwa community, Niger Delta. GARJEST 3, 006, 2014.

14. SHEKOOHIYAN S., MOUSSAVI G., NADDAFI K. The peroxidase-mediated biodegradation of petroleum hydrocarbons in a $\mathrm{H}_{2} \mathrm{O}_{2}$-induced $\mathrm{SBR}$ using in-situ production of peroxidase: biodegradation experiments and bacterial identification. J. Hazard. Mater. 313, 170, 2016.

15. TAM N.F.Y., WONG Y.S. Effectiveness of bacterial inoculum and mangrove plants on remediation of sediment contaminated with polycyclic aromatic hydrocarbons. Marine Pollut. Bull. 57, 716, 2008.

16. HAYS S.G. et al. Better together: engineering and application of microbial symbioses. Curr. Opin. Biotechnol. 36, 40, 2015.

17. KACZYŃSKA G., BOROWIK A., WYSZKOWSKA J. Soil dehydrogenases as an indicator of contamination of the environment with petroleum products. Water Air Soil Pollut. 226, 372, 2015.

18. MADDELA N.R, BURGOS R., KADIYALA V., CARRION A.R., BANGEPPAGARI M. Removal of petroleum hydrocarbons from crude oil in solid and slurry phase by mixed soil microorganisms isolated from Ecuadorian oil fields. Int. Biodeterior. Biodegradation. 108, 850, 2016.

19. SUTTON N.B., MAPHOSA F., MORILLO J.A., ABU AL-SOUD W., LANGENHOFF A.A., GROTENHUIS T., RIJNAARTS H.M.M., SMIDT H. Impact of long-term diesel contamination on soil microbial community structure. Appl. Environ. Microbiol. 79 (2), 619, 2013.

20. WOLIŃSKA A., KUŹNIAR A., SZAFRANEKNAKONIECZNA A., JASTRZĘBSKA N., ROGUSKA E., STĘPNIEWSKA Z. Biological Activity of Autochthonic Bacterial Community in Oil-Contaminated Soil. Water, Air, Soil Pollut. 227 (5), 130, 2016.

21. POPUTNIKOV T.O., TEREKHOVA V.A., YAKOVLEV A.S. Assessment of the negative impact of the solid domestic wasteland on soils by biotic indicators. Ecol. Industry of Russia 3, 51, 2010.

22. DELMONT T.O., ROBE P., CECILLON S., CLARK I.M., CONSTANCIAS F., SIMONET P. Accessing the soil metagenome for studies of microbial diversity. Appl. Environ. Microbiol. 77 (4), 1315, 2011.

23. SHUO J., ZHENSHAN L., YANBING L., JUN Y., WEIMIN C., GEHONG W. Bacterial communities in oil contaminated soils: Biogeography and cooccurrence patterns. Soil Biol. Biochem. 98, 64, 2016.

24. SILVA I.S., SANTOS E.C., MENEZES C.R., FARIA A.F., FRANCISCON E., GROSSMAN M., DURRANT L.R. Bioremediation of a polyaromatic hydrocarbon contaminated soil by native soil microbiota and bioaugmentation with isolated microbial consortia. Bioresour. Technol. 100 (20), 4669, 2009.

25. YANG S. WEN XI, SHI Y., LIEBNER S., JIN H., PERFUMO A. Hydrocarbon degraders establish at the costs of microbial richness, abundance and keystone taxa after crude oil contamination in permafrost environments. Sci. Rep. 6, 37473, 2016.

26. ZHANG J., XUE Q., GAO H., LAI H., WANG P. Bacterial degradation of crude oil using solid formulations of bacillus strains isolated from oil-contaminated soil towards microbial enhanced oil recovery application. RSC. Adv. 6, 5566, 2016. 
27. CHIKERE C.B., AZUBUIKE C.C., FUBARA E.V. Shift in microbial group during remediation by enhanced natural attenuation (RENA) of a crude oil-impacted soil: a case study of Ikarama Community, Bayelsa Nigeria. Biotechnol. 7 (2), 152, 2017.

28. DAS K., MUKHERJEE A.K. Crude petroleumoil biodegradation effiency of Bacillus subtilis and Pseudomonas aeruginosa strains isolated from a petroleum-oil contaminated soil from North-East India. Bioresour. Technol. 98 (7), 1339, 2007.

29. JOHN J., ELIAS R.S., BALASUNDARAN M., KURIAN P. Biodegradation of kerosene by bacterial isolates. Int. J. Life Sci. Res. 3, 68, 2015.

30. MORALES-GUZMÁN G., FERRERA-CERRATO R. Diesel degradation by emulsifying bacteria isolated from soils polluted with weathered petroleum hydrocarbons. Appl. Soil Ecol. 121, 127, 2017.

31. TABARI KH., TABARI M. Characterization of a biodegrading bacterium, Bacillus subtilis, isolated from oil-contaminated soil Int. J. Environ. Sci. Technol. 14, 2583, 2017.

32. ABBASIAN F., LOCKINGTON R., MEGHARAJ M., NAIDU R. The biodiversity changes in the microbial population of soils contaminated with crude oil. Curr. Microbiol. 72 (6), 663, 2016.

33. COVINO S., STELLA T., D'ANNIBALE A., LLADO S., BALDRIAN P., CVANCAROVA M., CAJTHAML T., PETRUCCIOLI M. Comparative assessment of fungal augmentation treatments of a fine-textured and historically oil-contaminated soil. Sci. Total Environ. 56, 250, 2016.

34. JONES D.M., HEAD I.M., GRAY N.D., ADAMS J.J., ROWAN A.K., AITKEN C.M., BENNETT B., HUANG H., BROWN A., BOWLER B.F.J, OLDENBURG T. Crude-oil biodegradation via methanogenesis in subsurface petroleum reservoirs. Nature. 451, 176, 2008.

35. TABATABAEE M.S., MAZAHERI ASSADI M. Studying the indigenous crude oil methanogens and their potential. J. Int. Environ. Appl. Sci. 8, 503, 2013.

36. BAO Y., XU Z., LI Y., YAO Z., SUN J., SONG H. High-throughput metagenomic analysis of petroleumcontaminated soil microbiome reveals the versatility in xenobiotic aromatics metabolism. J Environ. Sci. 56, 25, 2016.

37. LORCH H.J., BENCKIESER G., OTTOW J.C.G. Basic methods for counting microorganisms in soil and water. In: Alef K, Nannipieri P. Eds., Academic press: New York, 146, 1995.

38. GERHARDT P. Manual of methods for general bacteriology. In: Gerhardt P., Murray R.G.E. Eds., Washington D.C: American society for Microbiology, 1981.

39. AL-BAHRY S.N., AL-WAHAIBI Y.M., AL-HINAI B., JOSHI J.S., ELSHAFIE A.E., AL-BEMANI A.S., AL-SABAHI J. Potential in heavy oil biodegradation via enrichment of spore forming bacterial consortia. J. Pet. Explor. Prod. Technol. 6, 787, 2016.

40. FENG W., SWIFT S., SINGHAL N. Effects of surfactants on cell surface tension parameters and hydrophobicity of Pseudomonas putida 852 and Rhodococcus erythropolis 3586. Colloids Surf. B. Biointerfaces 105, 43, 2013.

41. KIS Á.E., LACZI K., ZSÍROS S., KÓS P., TENGÖLICS R., BOUNEDJOUM N., KOVÁCS T., RÁKHELY G., PEREI K. Characterization of the Rhodococcus sp. MK1 strain and its pilot application for bioremediation of diesel oil-contaminated soil. Acta Microbiol. Immunol. Hung. 64, 463, 2017.
42. PI Y., BAO M., LI Y., LI G., LU J., SUN P. Characterization of crude oil degrading microbial cultures isolated in Qingdao China. RSC Adv. 5, 97665, 2015.

43. SUN W.Y.D., GAO P., FU M., TA K., LI J. Microbial communities inhabiting oil-contaminated soils from two major oilfields in Northern China: Implications for active petroleum-degrading capacity. J. Microbiol. 53 (6), 371, 2015.

44. THAPA B., KC A.K., GHIMIRE A. A review on bioremediation of petroleum hydrocarbon contaminants in soil. Kathmandu Univ. J. Sci. Eng. Technol. 8 (1), 164, 2012.

45. SAUL D.J., AISLABIE J.M., BROWN C.E., HARRIS L., FOGHT J.M. Hydrocarbon contamination changes the bacterial diversity of soil from around Scott Base, Antarctica. FEMS Microbiol. Ecol. 53 (1), 141, 2005.

46. VAZQUEZ S., NOGALES B., RUBERTO L. Bacterial community dynamics during bioremediation of diesel oilcontaminated Antarctic soil. Microb. Ecol. 57 (4), 598, 2009.

47. EKHAISE F.O., NKWELLE J. Microbiological and physicochemical analyses of oil contaminated soil from major motor mechanic workshops in Benin city Metropolis, Edo State, Nigeria J. Appl. Sci. Environ. Manage 15 (4), 597, 2011.

48. MA X.K., DING N., PETERSON E.C. Bioaugmentation of soil contaminated with high-level crude oil through inoculation with mixed cultures including Acremonium sp. Biodegradation 26 (3), 259, 2015.

49. MOHSENZADEH F., CHEHREGANI RAD A., AKBARI $M$. Evaluation of oil removal efficiency and enzymatic activity in some fungal strains for bioremediation of petroleum-polluted soils. Iranian J. Environ. Health Sci. Eng. 9 (1), 26, 2012.

50. MUNEER A.Q., TAYYABA K., MUNIBA J., SAFIA A. Isolation and Characterization of a biosurfactant-producing Fusarium sp. BS-8 from oil contaminated soil. Biotechnol. Prog. 30 (5), 1065, 2014.

51. VANISHREE M., THATHEYUS A.J., RAMYA D. Biodegradation of petrol using the fungus Penicillium $s p$. Sci. Int. 2 (1), 26, 2014.

52. ZOHREH S., MOHSENZADEH F. Removing of crude oil from polluted areas using the isolated fungi from Tehran oil refinery. Soil and Sed. Contam. 25, 536, 2016.

53. ESMAEILI A., SADEGHI E. The efficiency of Penicillium commune for bioremoval of industrial oil Int. J. Environ. Sci. Technol. 11, 271, 2014.

54. MADDELA N.R., BURGOS R., KADIYALA V., CARRION A.R., BANGEPPAGARI M. Removal of petroleum hydrocarbons from crude oil in solid and slurry phase by mixed soil microorganisms isolated from Ecuadorian oil fields. Int. Biodeterior. Biodegradation. 108, 85, 2016.

55. UMANA E.J., AKWAJI P.I., MARKSON A.A. Bioremediation of spent engine oil contaminated soil by using fungus, Penicillium sp. I. L. N. S. 59, 82, 2016.

56. ZAFRA G., ABSALON A.E., CORTÉS-ESPINOSA D.V. Isolation and selection of a highly tolerant microbial consortium with potential for PAH biodegradation from heavy crude oil-contaminated soils. Water, Air and Soil Pollut. 225, 1826, 2014.

57. LANG F.S., DESTAIN J., DELVIGNE F., DRUART P., ONGENA M., THONART P. Characterization and evaluation of the potential of a diesel-degrading bacterial consortium isolated from fresh mangrove sediment. Water Air Soil Pollut. 227, 58, 2016. 
58. SHARMA A., SINGH S.B., SHARMA R., CHAUDHARY P. Enhanced biodegradation of PAHs by microbial consortium with different amendment and their fate in insitu condition. J. Environ. Manage. 181, 728, 2016.
59. WANG S., NOMURA N., NAKAJIMA T., UCHIYAMA $\mathrm{H}$. Case study of the relationship between fungi and bacteria associated with high-molecular-weight polycyclic aromatic hydrocarbon degradation. J. Biosci. Bioeng. 113 (5), 624, 2012. 